\title{
Evaluating the Antimicrobial Efficacy of Root Canal Irrigants Against Candida Albicans and Enterococcus Faecalis: In vitro study
}

\author{
Irigasyon Solüsyonlarının Candida albicans ve Enterococcus faecalis Üzerindeki \\ Antimikrobiyal Etkinliklerinin Değerlendirilmesi: In vitro çalışma
}

\author{
Ilgın AKÇAY $\quad$ Berivan Tuğba TÜRK ${ }^{1} \quad$ Beyser PişKiN $^{1} \quad$ Bilge Hakan ŞEN ${ }^{1} \quad$ Tansel ÖZTÜRK $^{2}$
}

Ege Üniversitesi, ${ }^{1}$ Diş Hekimliği Fakültesi Endodonti AD, ${ }^{2}$ Fen Fakültesi Biyoloji AD, IZMiR

\begin{abstract}
To assess the antimicrobial efficacy of super oxidized water (SOW), $\mathrm{NaOCl}$, chlorhexidine, and EDTA against $E$. faecalis and C. albicans using disc diffusion (DDT) and direct contact (DCT) tests. In DDT, $20 \mu$ l of each solution was impregnated to paper discs and the discs were placed on agar plates containing either microorganism. The inhibition zones were measured after $24 \mathrm{~h}$. In DCT, each solution was placed on the surface of agar plates that had been inoculated with each microorganism. After predetermined periods, transfers were made from the contact area between the test specimen and the cultured agar and from the area that had not been in contact with the test specimens. The results were read as presence/absence of microbial growth and statistical analysis was performed using Kruskal-Wallis and Mann-Whitney U-test test. In the DDT, all solutions exhibited inhibition zones in varying degrees. CHX and EDTA showed significant antimicrobial properties against $E$. faecalis and $C$. albicans $(p<0.05)$. In the DCT, all irrigants eliminated both microorganisms in all time intervals ( $p>0.05$ ). Albeit, EDTA's antimicrobial activity increased with the prolonged contact time. $\mathrm{NaOCl}, \mathrm{CHX}$, and EDTA were effective against both microorganisms. However, the antimicrobial efficiency of SOW differed between tests.
\end{abstract}

Keywords: C. albicans, E. faecalis, irrigation

\section{Özet}

Süper oksit su (SOW), NaOCl, klorheksidin ve EDTA'nın E. faecalis ve C. albicans üzerindeki antimikrobiyal etkinliklerinin disk difüzyon (DDT) ve direkt temas testleri (DCT) ile değerlendirilmesidir. Disk difüzyon testinde, her solüsyondan $20 \mu$ l kâğıt disklere emdirilerek mikroorganizmaların bulunduğu agar kaplarına yerleştirildi. Inhibisyon zonları 24 saat sonunda ölçüldü. Direkt temas testinde, mikroorganizmaların ekildiği agar kaplarına solüsyonlar konuldu. Belirlenmiş sürelerde örnek ve agar kültürünün temas ettiği ve etmediği alanlardan transferler gerçekleştirildi. Ölçümler mikrobiyal büyüme var/yok olarak okundu ve Kruskal-Wallis ve Mann-Whitney U testleri kullanılarak istatistiksel analiz yapıldı. Disk difüzyon testinde, tüm solüsyonlarda, farklı seviyelerde inhibisyon zonu gözlendi. E. faecalis ve C. albicans karşısında CHX ve EDTA anlamlı antimikrobiyal etkinlik gösterdi $(p<0,05)$. Direkt temas testinde, tüm test solüsyonlar her iki mikroorganizmayı tüm zaman aralıklarında elimine etti $(p>0,05)$. EDTA'in etkinliğinin uzayan temas süresi ile doğru orantılı olarak arttı̆ı saptandı. NaOCl, CHX ve EDTA her iki test mikrorganizmalar üzerinde etkili bulundu. Ancak SOW'un etkinliği iki test yönteminde farklılık gösterdi.

Anahtar sözcükler: C. albicans, E. faecalis, irigasyon

\section{Introduction}

It is important to use chemical solutions for disinfection and cleaning of the canals during chemo-mechanical preparation. Because the root canal system has a complex anatomy and limited access, microorganisms may still remain in dentinal tubules and re-infect the root canals by propagation. ${ }^{1}$ Several antimicrobial irrigation solutions including sodium hypochlorite ( $\mathrm{NaOCl}$ ), ethylenediamine-tetraacetic acid (EDTA), and chlorhexidine (CHX) are used during root canal treatment. $^{2,3}$

Sodium hypochlorite has long been the irrigant of choice for endodontic procedures. It dissolves 
organic tissues, and has a broad spectrum antimicrobial activity. ${ }^{3}$ However, $\mathrm{NaOCl}$ has extremely toxic effect on the periapical tissues if it is forced beyond the apex. ${ }^{4}$

EDTA is mainly used for its chelating ability and to remove smear layer from the canal walls. It has been claimed that EDTA has no disinfecting effect, but there are also studies that showed its antimicrobial and antifungal activity. ${ }^{5}$

The use of CHX as an irrigation solution during root canal treatment has been suggested based on its antimicrobial activity and having less malodor and cytotoxic effect than $\mathrm{NaOCl}^{6}$ Chlorhexidine has shown to be a potent broadspectrum antimicrobial agent that has the advantage of substantivity. ${ }^{3}$ Despite of all these advantages, it does not dissolve organic tissue. ${ }^{7}$

Electrochemical activation was first offered and developed by some of the Russian scientists for over the course of the past 34 years. ${ }^{8}$ Since then, electrolyzed super oxidized waters (SOW) have been shown to inactivate many microorganisms contributing to endodontic infections. ${ }^{9}, 10$ There are some studies that investigated the smear and debris removal efficacy of electro-chemically activated water (ECA), compared with routine irrigation solutions or used in combination. ${ }^{11}$ The results of these studies showed that electrochemically activated solutions were as effective as the routine irrigation agents. There are only a few studies that evaluated the antimicrobial effectiveness of ECA in endodontic literature. ${ }^{10}$

${ }^{12}$ The bactericidal effect of electrolyzed neutral water (ENW) was examined against 17 strains of bacteria and 1 strain of fungus (C. albicans) and found that ENW showed a bactericidal or growth-inhibitory effect against the strains. ${ }^{10}$ Marais et al. ${ }^{12}$, on the other hand, showed that ECA was not as effective as $\mathrm{NaOCl}$ against 2 obligate and 2 facultative anaerobic bacteria.

The purpose of this study was to compare the antimicrobial effectiveness of SOW, $2.5 \% \mathrm{NaOCl}$, $2 \%$ CHX, and 5\% EDTA against E. faecalis and
C. albicans using the disc diffusion and direct contact tests.

\section{Materials and Methods}

Disc diffusion test (DDT)

Standard E. faecalis (ATCC 29212) and C. albicans (ATCC 10239) strains obtained from the American Type Culture collection (ATCC, Rockville MD, USA) were used for this study. The strains were inoculated in Tryptic Soy Broth (TSB) (Merck) and incubated at $37^{\circ} \mathrm{C}$ for 24 hours. Microbial cells were resuspended in saline to give a final concentration of $\sim 2.0 \times 10^{7}$ cells $/ \mathrm{mL}$ (E. faecalis) and $\sim 2.0 \times 10^{5}$ (C. albicans) cells $/ \mathrm{mL}$, similar to that of tube \#0.5 of the McFarland scale. For disc diffusion test, petri plates with $20 \mathrm{~mL}$ of Tryptic soy agar (TSA) (Merck) were inoculated with $0.1 \mathrm{~mL}$ of one of the microbial suspensions. Sterile Paper discs (Oxoid, Oxoid Antibacterial Susceptibility Blank Test Disk, Hampshire, UK) were soaked with $20 \mu \mathrm{L}$ of one of the tested solutions. Then, the paper discs were placed in agar plates inoculated with $E$. faecalis or C. albicans. The experiment was performed 4 times in triplicate under aseptic conditions. Nystatin (antifungal; Mycostatin, Bristol-Myers Squibb, NJ, USA) and Ceftazidime (antibacterial; Fortum, Glaxo Smith Kline, Victoria, Australia) were the agents used in control groups. The plates were re-incubated aerobically at $37^{\circ} \mathrm{C}$ for $24 \mathrm{~h}$. Then, the diameter of the zone of inhibition was measured in millimeters with the help of an inhibition zone measuring scale and the values recorded. The point of abrupt diminution of growth, which corresponds to the point of complete inhibition of growth, was taken as the zone edge.

\section{Direct contact test (DCT)}

The strains were inoculated in TSB (Merck) and incubated at $37^{\circ} \mathrm{C}$ for 24 hours as described previously. Microbial cells were resuspended in saline to give a final concentration of $\sim 9 \times 10^{6}$ cells $/ \mathrm{mL}$ for $E$. faecalis and $\sim 1.0 \times 10^{5}$ cells $/ \mathrm{mL}$ for C. albicans similar to that of tube \#0.5 of 
the McFarland scale. Microbial suspensions were used in 30 minutes.

One $\mathrm{mL}$ of bacterial or fungal suspensions was centrifuged in micro tubes. Nine $\mathrm{mL}$ of each test solution was added to the $1 \mathrm{~mL}$ of bacterial or fungal suspension and vortexed. The suspensions were kept in contact with each irrigation solution in varying periods (30 seconds, 1,3 and 5 minutes). To avoid the residual antimicrobial effect of the test solutions, 3\% Tween $80+0.3 \%$ $\mathrm{L}-\alpha$-Lecithin was used for chlorhexidine and: $0.5 \%$ sodium thiosulphate for $\mathrm{NaOCl}$ as inactivation agents.

Following neutralization, one $\mathrm{mL}$ of the test solutions was transferred into the tubes containing $9 \mathrm{ml}$ of sterile saline solution. Of this $10^{-1}$ dilution, a serial decimal dilution was prepared again in saline solution up to $10^{-4}$. From each dilution $1 \mathrm{~mL}$ was pipetted in petri dishes. TSA (Merck) medium was used for $E$. faecalis and Sabouraud Dextrose Agar (SDA) $\left(\right.$ Difco $^{\mathrm{TM}}$ ) medium was used for $C$. albicans. Plates were incubated at $37^{\circ} \mathrm{C}$. The colonies were counted after 24 hours and expressed as colony forming units (cfu). All assays were conducted 4 times in triplicate under aseptic conditions.

Data were statistically analyzed by KruskalWallis to reveal significant differences among the groups. For pairwise comparisons, MannWhitney U-test was used after Bonferroni correction $(p=0.05)$.

\section{Results}

\section{Disc diffusion test}

In the disc diffusion test, no bacterial growth was determined in the negative control while there was normal bacterial growth in the positive group.

Table 2. Inhibition rate of $E$. faecalis and C. albicans after contact with test solutions.

\begin{tabular}{|c|c|c|c|c|c|c|c|c|}
\hline \multirow[b]{3}{*}{ Contact time } & \multicolumn{8}{|c|}{ Solutions } \\
\hline & \multicolumn{2}{|c|}{ SOW } & \multicolumn{2}{|c|}{ EDTA } & \multicolumn{2}{|c|}{$\mathrm{NaOCl}$} & \multicolumn{2}{|c|}{$\mathrm{CHX}$} \\
\hline & E. faecalis & C. albicans & E. faecalis & C. albicans & E. faecalis & C. albicans & E. faecalis & C. albicans \\
\hline 30 seconds & $100 \%$ & $100 \%$ & $98,66 \%$ & $98,8 \%$ & $100 \%$ & $100 \%$ & $100 \%$ & $100 \%$ \\
\hline 1 minute & $100 \%$ & $100 \%$ & $98,88 \%$ & $99,5 \%$ & $100 \%$ & $100 \%$ & $100 \%$ & $100 \%$ \\
\hline 3 minute & $100 \%$ & $100 \%$ & $99,90 \%$ & $99,5 \%$ & $100 \%$ & $100 \%$ & $100 \%$ & $100 \%$ \\
\hline 5 minute & $100 \%$ & $100 \%$ & $99,93 \%$ & $100 \%$ & $100 \%$ & $100 \%$ & $100 \%$ & $100 \%$ \\
\hline
\end{tabular}

The mean diameters of the inhibition zones created by each irrigation solution against the tested strains are shown in Table 1 . All test solutions inhibited growth of $E$. faecalis and C. albicans. The antimicrobial efficacy of SOW was found to be lower than the other agents $(\mathrm{p}<0.05)$. EDTA demonstrated higher antifungal efficacy than all other test solutions including main antifungal agent (Nystatin) $(\mathrm{p}<0.05)$. In addition, CHX, $\mathrm{NaOCl}$, and Nystatin showed significant antifungal properties. However, SOW was not effective against $C$. albicans.

Table 1. Average of the inhibition zones of all test solutions and control groups (antifungal or antibacterial agents) against each microorganism

\begin{tabular}{lll}
\hline \multirow{2}{*}{ Test solutions } & \multicolumn{2}{c}{ Microorganisms } \\
\cline { 2 - 3 } EDTA & E. faecalis & C. albicans \\
CHX & $19 \pm 0.30$ & $34 \pm 0.0$ \\
SOW & $19 \pm 0.45$ & $18 \pm 0.30$ \\
NaOCl & $7 \pm 0.94$ & $8 \pm 0.90$ \\
Antifungal (Nystatin) & $14 \pm 0.70$ & $20 \pm 0.35$ \\
Antibacterial (ceftazidime) & $20 \pm 0.0$ & $19.5 \pm 0.40$ \\
Distilled water & - & - \\
\hline
\end{tabular}

Values are presented as $\mathrm{mm} \pm \mathrm{SD}$

\section{Direct contact test}

The amount of microbial reduction is shown in Table 2. All solutions eliminated $E$. faecalis and C. albicans effectively at any test period. Statistical analyses showed no difference among the solutions $(p>0.05)$. Although there was no difference among test periods in antimicrobial capacity of all solutions ( $p>0.05$ ), EDTA efficiency against both microorganisms increased in time. 


\section{Discussion}

The antimicrobial efficacy of irrigation solutions has long been investigated with different test methods. Each method has its own advantages and disadvantages. DDT is one of the most commonly used methods in vitro. In DDT, selected microorganisms are in direct contact with the tested materials. The antimicrobial efficiency of the tested materials is assessed by measuring the diameter of the inhibition zone after a certain time of incubation..$^{13}$ It has been reported that the diameter of the inhibition zone depended on the tested material's diffusion ability and solubility in the agar medium. ${ }^{13}$ Therefore, DDT has a disadvantage of not determining the exact efficacy of the test materials. However, it has been also emphasized that the diffusion tests were reliable and compatible with the other antimicrobial test methods. $^{14}$ Furthermore, in the endodontic literature, agar diffusion tests were used to evaluate the effectiveness of the disinfectants and irrigation solutions. ${ }^{15}$ Moreover, this is an easy and less technique sensitive method.

DCT is another test method in which a constant quantity of the disinfectant solution is mixed with a microbial suspension for a certain incubation period and the antimicrobial activity is confirmed through culture of the resultant mixture in a medium. ${ }^{16}$ According to the variables such as colony forming units in the microbial suspension and the contact time, dissimilar results might be obtained. ${ }^{13}$ DCT was found to be a pragmatic method, because each study can get comparable results and the test is independent of test material's solubility and diffusion capability. ${ }^{13}$ DCT is suitable for irrigants; therefore, it has been used in endodontic studies. ${ }^{13,17}$

The combination of $3 \%$ Tween $80+0.3 \% \mathrm{~L}-\alpha-$ Lecithin and $0.06 \%$ sodium- thiosulphate were found to be effective and reliable neutralizers for $\mathrm{CHX}$ and $\mathrm{NaOCl}^{17}$ In order to prevent the residual action of the irrigation solutions 3\% Tween $80+0.3 \%$ L- $\alpha$-Lecithin for CHX and
$0.5 \%$ sodium- thiosulphate for $\mathrm{NaOCl}$ were used in the study.

EDTA is a calcium chelating agent and capable of removing the smear layer. ${ }^{18}$ The self-limiting properties of EDTA demonstrate that its action goes on until all of its cationic receptors are saturated with calcium ions and therefore demineralization terminates when this equilibrium has been reached. ${ }^{19}$ Even though, Tween $80+40 \%$ sodium bisulfate + sodium thiosulfate pentahydrate + calcium chloride were used to neutralize EDTA in a previous study, ${ }^{20}$ owing to its calcium removing ability from the culture media, no neutralizer was used for EDTA in this study. It has been shown that EDTA causes a zone of inhibition on an agar plate, but fails to reduce the number of viable microbes even after 24 hour incubation in a test tube. ${ }^{21}$ However, in this study EDTA was as effective as $\mathrm{NaOCl}$ and CHX in DCT, only its effectiveness was time dependent.

Nair et al. ${ }^{1}$ suggested that in the majority of root-filled human teeth with therapy-resistant periapical lesions, microorganisms such as $E$. faecalis and fungi might persist and might play a significant role in endodontic treatment failures. Yeasts are known to be opportunistic pathogens which are resistant to the host defense mechanisms. It has been demonstrated that C. albicans can form a biofilm layer on the surface of dental hard tissues with strong attachment. ${ }^{22}$ E. faecalis is rarely found in primary root canal infections, but frequently isolated from the root canals of teeth with failed endodontic treatment. ${ }^{1}$ E. faecalis and $C$. albicans are the most resistant microorganisms which are found in endodontic microflora and have been used in several previous studies on the efficacy of endodontic irrigants. ${ }^{15}$

Our results showed that 5\% EDTA and 2\% CHX were effective medicaments against $E$ faecalis in vitro. $\mathrm{NaOCl}(2.5 \%)$ also had a pronounced effectiveness against this bacterium. Our findings for $\mathrm{CHX}$ and $\mathrm{NaOCl}$ were in accordance with the literature. ${ }^{23}$ Fidalgo et al. ${ }^{24}$ detected a 
high inhibitory effect on the metabolic activity of $E$. faecalis when the microorganisms were incubated with $17 \%$ EDTA.

The efficacy of SOW was lower than the other three test solutions in the present study. It has been found that SOW was ineffective against E. faecalis strain, in a previous study. ${ }^{9}$ It has been shown that the disinfecting actions of super-oxidized water are heavily reduced in the presence of organic contamination. However, the results of DCT showed that SOW prevented the growth of this bacterium.

According to our results, EDTA was the most effective medicament to inhibit the growth of the C. albicans. Ramage et al. ${ }^{25}$ indicated that cations, such as calcium, are essential for morphogenesis and cellular signaling events and biofilm formation in C. albicans. Its effectiveness against $C$. albicans would be associated to yeast-to-mycelium transition blockage. ${ }^{25}$ Sen et al. ${ }^{5}$ demonstrated that $17 \%$ EDTA was the most effective antifungal solution amongst the routine antifungal agents. In the present study, $\mathrm{NaOCl}$ and $\mathrm{CHX}$ showed detectable effect against this fungus. This finding was in accordance with the previous researches. ${ }^{23}$ Landa-Solis et al. ${ }^{8}$ found that SOW effectively eliminated C. albicans. Although SOW exhibited an inhibition zone for the strain, our results revealed that it was not as effective as the other chemical agents. The inferior antimicrobial activity of SOW produced in the DDT might be related to the material's poor diffusibility in agar medium.

\section{Conclusions}

Within the limitations of this in vitro study, it may be concluded that 5\% EDTA, 2.5\% $\mathrm{NaOCl}$ and $2 \%$ CHX are effective antimicrobial agents against the $E$. faecalis and $C$. albicans. The antimicrobial effectiveness of SOW and EDTA differed between two tests. SOW caused a bacterial load decrease although being less effective than the rest of the tested solutions. Further studies are needed to recommend SOW as a routine irrigation solution.

\section{References}

1. Nair PN, Sjögren U, Krey G, Kahnberg KE, Sundqvist G. Intraradicular bacteria and fungi in root-filled, asymptomatic human teeth with therapy-resistant periapical lesions: a long-term light and electron microscopic follow-up study. $J$ Endod 1990; 16: 580-588.

2. Byström A, Sundqvist G. Bacteriologic evaluation of the effect of 0.5 percent sodium hypochlorite in endodontic therapy. Oral Surg Oral Med Oral Pathol Oral Radiol Endod 1983; 55: 307-312.

3. Kuruvilla JR, Kamath MP. Antimicrobial activity of $2.5 \%$ sodium hypochlorite and $0.2 \%$ chlorhexidine gluconate separately and combined, as endodontic irrigants. J Endod 1998; 24: 472-476.

4. Harrison JW, Svec TA, Baumgartner JC. Analysis of clinical toxicity of endodontic irrigants. J Endod 1978; 4: 6-11.

5. Sen BH, Akdeniz BG, Denizci AA. The effect of ethylenediamine-tetraacetic acid on Candida albicans. Oral Surg Oral Med Oral Pathol Oral Radiol Endod 2000; 90: 651-655.

6. Dametto FR, Ferraz CC, de Almeida Gomes BP, Zaia AA, Teixeira FB, de Souza-Filho FJ. In vitro assessment of the immediate and prolonged antimicrobial action of chlorhexidine gel as an endodontic irrigant against Enterococcus faecalis. Oral Surg Oral Med Oral Pathol Oral Radiol Endod 2005; 99: 768-772.

7. Jeansonne M, White R. A comparison of $2.0 \%$ chlorhexidine gluconate and $5.25 \%$ sodium hypochlorite as antimicrobial endodontic irrigants. J Endod 1994; 20: 276-278.

8. Landa-Solis C, González-Espinosa D, GuzmánSoriano B, Snyder M, Reyes-Terán G, Torres K, Gutierrez AA. Microcyn: a novel super-oxidized water with neutral $\mathrm{pH}$ and disinfectant activity. Hosp Infect 2005; 61: 291-299.

9. Davis JM, Maki J, Bahcall JK. An In Vitro Comparison of the antimicrobial Effects of Various Endodontic Medicaments on Enterococcus faecalis. J Endod 2007; 33: 567-569.

10. Horriba $N$, Hiratsuka $K$, Onoe $T$, et al. Bactericidal effect of electrolyzed neutral water on bacterial isolated from infected root canals. Oral Surg Oral Med Oral Pathol Oral Radiol Endod 1999; 87: 83-87.

11. Hata G, Hayami S, Weine FS, Toda T. Effectiveness of oxidative potential water as a root canal irrigant. Int Endod J 2001; 34: 308-37.

12. Marais JT, Williams WP. Antimicrobial effectiveness of electro-chemically activated water as an endodontic irrigation solution. Int Endod $J$ 2001; 34: 237-23. 
13. Estrela C, Rodrigues de Araújo Estrela C, Bammann LL, Pecora JD. Two methods to evaluate the antimicrobial action of calcium hydroxide paste. J Endod 2001; 27: 720-723.

14. Mayrhofer S, Domig KJ, Mair C, Zitz U, Huys G, Kneifel W. Comparison of broth microdilution, Etest, and agar disk diffusion methods for antimicrobial susceptibility testing of Lactobacillus acidophilus group members. Appl Environ Microbiol 2008; 74: 3745-3748.

15. Gomes BP, Souza SF, Ferraz CC, Teixeira FB, Zaia AA, Valdrighi L, Souza-Filho FJ. Effectiveness of $2 \%$ chlorhexidine gel and calcium hydroxide against Enterococcus faecalis in bovine root dentine in vitro. Int Endod J 2003; 36: 267-275.

16. Cremieux A, Fleurette J. Methods of testing disinfectants. In: Block SS, ed. Disinfection, sterilization and preservation. 4th ed. Philadelphia, PA: Lea \& Febiger Publishers; 1991. pp. 1009-1027.

17. Zamany A, Spångberg LS. An effective method of inactivating chlorhexidine. Oral Surg Oral Med Oral Pathol Oral Radiol Endod 2002; 93: 617620.

18. Hülsmann M, Heckendorff M, Lennon A. Chelating agents in root canal treatment: mode of action and indication for their use. Int Endod $J$ 2003; 36: 810-830.

19. Seidberg B, Schilder H. An evaluation of EDTA in endodontics. Oral Surg Oral Med Oral Pathol Oral Radiol Endod 1974; 37: 609-620.

20. Khedmat, Aligholi M, Sadeghi S. Influence of bovine serum albumin on the antibacterial activity of endodontic irrigants against Enterococcus faecalis. Int Endod J 2009; 4: 139-143.
21. Ingle $\mathrm{J}$, Bakland $\mathrm{L}$, Baumgartner J. Ingle's endodontics 6. BC Decker Inc., Canada, 2008, 995.

22. Sen BH, Safavi KE, Spångberg LS. Colonization of Candida albicans on cleaned human dental hard tissues. Arch Oral Biol 1997; 42: 513-520.

23. Estrela C, Ribeiro RG, Estrela CR, Pécora JD, Sousa-Neto MD. Antimicrobial effect of $2 \%$ sodium hypochlorite and $2 \%$ chlorhexidine tested by different methods. Braz Dent $J$ 2003; 14: 5862.

24. Fidalgo TK, Barcelos R, Portela MB, Soares RM, Gleiser R, Silva-Filho FC. Inhibitory activity of root canal irrigants against Candida albicans, Enterococcus faecalis and Staphylococcus aureus. Braz Oral Res 2010; 24: 406-412.

25. Ramage G, Wickes BL, López-Ribot JL. Inhibition on candida albicans biofilm formation using divalent cotion chelators (EDTA). Mycopathologia 2007; 164: 301-6.

\section{Yazışma Adresi:}

Uzm. Dr. Ilgın AKÇAY

Ege Üniversitesi,

Diş Hekimliği Fakültesi,

Endodonti AD,

35100 Bornova - IZMIR

Tel : (232) 3880328

E-posta : ilgin.akcay@ege.edu.tr 